\title{
ON THE HUMAN RIGHTS QUESTION
}

Paul O'Connell

\begin{abstract}
There is a marked disjuncture today between the generalised critique and rejection of human rights by many progressive and critical commentators, and the embrace of the language of human rights by a variety of movements around the world engaged in struggles for social change. This divide between critical theory and critical practice raises important questions about whether and how movements for fundamental social change should engage with human rights. In contrast to a number of well-established critical dismissals of rights, this article argues, from within the Marxist tradition, that human rights can, and in some cases should, be deployed by social movements in their campaigns. However, reaching this conclusion requires developing an understanding of human rights that gives primacy to social struggle and to a nuanced understanding of the contradictory nature of human rights.
\end{abstract}

KEYwORDS: human rights - critique - Marxism - contradiction - struggle - social change

\section{INTRODUCTION}

Critiques of human rights abound. ${ }^{1}$ This is by no means a recent development, ${ }^{2}$ but the very ubiquity of the language of human rights in our age, ${ }^{3}$ means that a plethora of critiques of human rights have proliferated over the last forty years. While it is true that such critiques arise from various points along the ideological and political spectrum-at times making strange bedfellows of critical theorists and reactionary politicians—what we might, broadly, term 'the left' has provided particularly fertile ground for critical accounts of human rights. ${ }^{4}$ Notwithstanding these critiques, and a recent spate of declarations about

\footnotetext{
* Reader in Law, SOAS University of London. I am grateful to Daniel Attenborough, Samia Bano, Umut Özsu, Alfredo Saad-Filho, Nimer Sultany and Jen Wilkinson for helpful comments and suggestions on earlier drafts of this article; as ever, responsibility for any remaining shortcomings of style or substance are mine alone.

${ }^{1}$ For a summary of some of the main critiques of human rights see: David Chandler, 'Contemporary Critiques of Human Rights' in Goodhart (ed), Human Rights: Politics and Practice (2nd edn, OUP 2013) 107.

2 Jeremy Waldron (ed), Nonsense Upon Stilts: Bentham, Burke and Marx on The Rights of Man (Routledge 1987).

3 The 'rhetoric of human rights is omnipresent in the contemporary world'. Amartya Sen. 'The Global Reach of Human Rights' (2012) 29 Journal of Applied Philosophy 91, 91. Similarly, Moyn notes that human rights are 'one of the most central notions ... of our time'. Samuel Moyn, Human Rights and the Uses of History (Verso 2014) xii.

4 Anthony Chase, 'The Left on Rights: An Introduction' (1984) 62 Texas Law Review 1541; Duncan Kennedy, 'The Critique of Rights in Critical Legal Studies' in Brown and Halley (eds), Left Legalism/Left Critique (Duke University Press 2002) 178.
} 
This is the version of the article accepted for publication in Human Rights Quarterly published by John Hopkins University Press: https://www.press.jhu.edu/journals/human-rights-quarterly

Accepted version downloaded from SOAS Research Online: http://eprints.soas.ac.uk/24788/

the demise of human rights, ${ }^{5}$ social movements around the world continue to frame their struggles and demands, at least partly, through the language of human rights. This can be seen in struggles for housing in Spain and South Africa, ${ }^{6}$ land in Brazil, ${ }^{7}$ racial equality in the US, ${ }^{8}$ or water in Ireland, ${ }^{9}$ to name but a few. This presents us with an interesting disjuncture. Throughout the world millions of people are attempting to confront the misery and injustices heaped upon them by the contemporary global order through, in part, mobilising the language of human rights to advance and defend their interests. At the same time, many of the putative critics of this extant global order disdain, by implication, such efforts through a sometimes bald, ${ }^{10}$ sometimes sophisticated, ${ }^{11}$ critique and dismissal of human rights.

This disjuncture-between critical theory and critical practice-raises a number of crucial questions about the relationship between ideas and social movements, law and struggles to bring about social change, and, for present purposes, about the role of human rights in emancipatory politics. It raises, at a critical historical juncture, ${ }^{12}$ the fundamental question of how individuals and groups committed to fundamental social change should engage with human rights. The argument developed here, put briefly, is that while many of the critiques of human rights raise important concerns, they fail to meaningfully address the central question of the relationship between human rights and social struggles. In contrast to such critiques, it will be argued here that human rights can and should be deployed in emancipatory political projects today, but that reaching such a conclusion requires us to

\footnotetext{
${ }^{5}$ Stephen Hopgood, The Endtimes of Human Rights (Cornell University Press, 2013); and Eric Posner, The Twilight of Human Rights Law (OUP 2014).

${ }^{6}$ Ada Colau and Adrià Alemany, Mortgaged Lives: From the Housing Bubble to the Right to Housing (The Journal of Aesthetics \& Protest 2014); and Jackie Dugard, Tshepo Madlingozi and Kate Tissington, 'Rights Compromised or Rights Savvy? The Use of Rights-Based Strategies to Advance Socio-Economic Struggles by Abahlali baseMjondolo, the South African Shack-Dwellers Movement' in Garcia, Klare and Williams (eds), Social and Economic Rights in Theory and Practice (Routledge 2015) 23.

${ }^{7}$ Peter Houzager, 'The Movement of the Landless (MST), Juridical Field, and Legal Change in Brazil' in Santos and Rodríguez-Garavito (eds), Law and Globalization From Below (CUP 2005) 218.

${ }^{8}$ Fredrick Harris, 'The Next Civil Rights Movement?' (2015) 63(3) Dissent 34.

${ }^{9}$ Dan Finn, 'Ireland's Water Wars' (2015) 95 New Left Review 49.

10 Slavoj Zizek, 'Against Human Rights’ (2005) 34 New Left Review 115.

${ }^{11}$ Costas Douzinas, Human Rights and Empire (Routledge-Cavendish 2007).

12 The stakes of the current historical period-characterised by the general crisis of capitalism-are brought into sharp relief by Immanuel Wallerstein, who argues that: 'We may think of this period of systemic crisis as an arena of struggle for the successor system ... We are faced with alternative choices which cannot be spelled out in institutional detail, but may be suggested in broad outline. We can choose collectively a new system that essentially resembles the present one: hierarchical, exploitative and polarizing ... Alternatively we can choose a radically different system, one that has never previously existed-a system that is relatively democratic and relatively egalitarian'. Immanuel Wallerstein, 'Structural Crises' (2010) 62 New Left Review 133, 140-141.
} 
This is the version of the article accepted for publication in Human Rights Quarterly published by John Hopkins University Press: https://www.press.jhu.edu/journals/human-rights-quarterly

Accepted version downloaded from SOAS Research Online: http://eprints.soas.ac.uk/24788/

go beyond narrow, formalistic and overly juridical concepts of what human rights are, and stress the centrality of social and political struggle in the formulation and defence of human rights. ${ }^{13}$

As the positive argument for human rights in emancipatory politics developed here draws from and situates itself within the Marxist tradition, the article begins by setting out some of the key Marxist debates on the question of human rights. The aim here is to elucidate some of the interesting discussions that have taken place within Marxism, and to establish a basis for defending human rights from within the Marxist tradition. In the next section the main lines of a number of critiques of human rights, associated with Critical Legal Studies, will be sketched, to both demonstrate their importance and to raise some reservations about their veracity and efficacy. In the penultimate section, a positive case will be set out for the deployment of human rights in emancipatory political movements and projects today. As will become clear, this is by no means a blanket defence of human rights - even less so of dominant human rights discourses and practices_-but rather a qualified case for human rights in emancipatory politics, premised on a fundamental shift in how we conceive the politics of human rights.

\section{MARXist Debates on Human RightS}

There is a well-established common-sense that Karl Marx was an implacable critic of human rights, and that as a consequence the Marxist tradition is one that is inhospitable to claims for human rights. ${ }^{14}$ As is often the case with such common-sense positions, this is not true. There are, of course, statements that Marx made which could be interpreted as evincing a rejection of human rights, and there have been some in the Marxist tradition who have explicitly rejected human rights. ${ }^{15}$ But the reality is that notwithstanding his own

\footnotetext{
13 'Efforts to achieve human rights practice should be understood as struggles over power and resource that are often waged against or in spite of states and other powerful interests ... the specific history of struggles to achieve human rights practice suggests that grassroots organising and direct action, including forms of open resistance and disobedience, typically involving networks of nongovernmental (NGO), social movement (SMO), and community organisations, are the most commonly successful approaches ... to realising human rights in any lasting, meaningful way'. William T. Armaline, Davita Silfen Glasberg and Bandana Purkayastha, The Human Rights Enterprise (Polity Press 2015) 14-15.

${ }^{14}$ Leszek Kolakowsk, 'Marxism and Human Rights' (1983) 112 Daedalus 81; and L.J. Macfarlane, 'Marxist Theory and Human Rights' (1982) 17 Government and Opposition 414.

${ }^{15}$ See, for example, Isaac Balbus, 'Commodity Form and Legal Form: An Essay on the "Relative Autonomy" of the Law' (1977) 11 Law \& Society 215.
} 
This is the version of the article accepted for publication in Human Rights Quarterly published by John Hopkins University Press: https://www.press.jhu.edu/journals/human-rights-quarterly

Accepted version downloaded from SOAS Research Online: http://eprints.soas.ac.uk/24788/

ambitions, Marx (and has long-time collaborator Friedrich Engels) never developed a well worked out, detailed and consistent theory of law, state and rights. ${ }^{16}$

Consequently, Marx's views on rights are, for the most part, incomplete, inconsistent and ambiguous. Similarly, the broad Marxist tradition encompasses a range of views about whether Marxists can or should support human rights, and these arguments are also marked by the absence of a single, consistent line. This section provides an overview of Marx's main statements and arguments about human rights, before tracing some of the key debates within the Marxist tradition on the question of human rights. Finally, this section concludes by arguing that it is ambiguity and inconsistency, from Marx onwards, that defines the Marxist approach to human rights. Therefore, it will be argued here that there is ample room within Marxism as a tradition committed to human emancipation, ${ }^{17}$ for supporting and engaging with human rights, notwithstanding certain critical currents within Marx's own work, and that of later Marxists.

\section{i. Marx on Rights}

The necessary starting point for thinking about Marx's position on human rights is his 1843 essay On the Jewish Question. ${ }^{18}$ This essay was written as a response to Bruno Bauer's argument that if Jewish people in Germany were to receive political emancipation, the same civil and political rights as other Germans, ${ }^{19}$ they must first renounce (or, from Bauer's perspective, emancipate themselves) from Judaism. In an excoriating critique of Bauer's argument, Marx also engaged in a general reflection on the nature of rights as such. Crucial to Marx's analysis of rights, and their limitations, is the distinction he draws

\footnotetext{
${ }^{16}$ As Fine notes, Marx never 'pursued his critique of jurisprudence to the same systematic extent to which he pursued his critique of political economy'. Bob Fine, Democracy and the Rule of Law: Marx's Critique of the Legal Form (The Blackburn Press, 1984) 5. Similarly, Hunt argues that 'the whole of the classical Marxist tradition bequeathed a deathly silence about the constitutional and legal problems that must inevitably confront any project of socialist construction'. Alan Hunt, 'A Socialist Interest in Law' (1992) I/192 New Left Review 105, 110.

${ }^{17}$ For Fromm 'the very aim of Marx is to liberate man from the pressure of economic needs, so that he can be fully human', consequently Marxism is, first and foremost, a theory for human emancipation. Erich Fromm, Marx's Concept of Man (Continuum 2004) 3.

${ }^{18}$ Karl Marx, 'On the Jewish Question' in Tucker (ed), The Marx-Engels Reader (2 ${ }^{\text {nd }}$ edn, W.W. Norton \& Co. 1978) 26. For useful reflections on this work, see: Stathis Kouvelakis, 'The Marxian Critique of Citizenship: For a Rereading of On the Jewish Question' (2005) 104 South Atlantic Quarterly 707; and Wendy Brown, 'Rights and Identity in Late Modernity: Revisiting the "Jewish Question"" in Sarat and Kearns (eds), Identities, Politics and Rights (University of Michigan Press 1997) 85.

${ }^{19}$ This was 'the Jewish Question', as Rühle notes, those 'who then used this phrase, had in mind the political and civic liberation of the Jews from their exceptional position before the law, a position which was a relic of the Middle Ages'. Otto Rühle, Karl Marx: His Life and Work (Allen and Unwin 1929) 62.
} 
This is the version of the article accepted for publication in Human Rights Quarterly published by John Hopkins University Press: https://www.press.jhu.edu/journals/human-rights-quarterly

Accepted version downloaded from SOAS Research Online: http://eprints.soas.ac.uk/24788/

between political emancipation and buman emancipation. The former can be achieved by the conferral of civil and political rights, but is formal and limited; the latter is substantive, genuine and can only be achieved through transcending existing social relations (capitalism), and collapsing the division between political citizens active in and through the state and private individuals who exist in 'civil society'. ${ }^{20}$

Starting from this premise, Marx argues that 'the so-called rights of man, as distinct from the rights of the citizen, are simply the rights of a member of civil society, that is, of egoistic man, of man separated from other men and from the community'. ${ }^{21}$ To demonstrate this, Marx identifies what he sees as the core rights in the French Declaration of the Rights of Man and the Citizen (equality, liberty, security and property) and sets out to show the necessarily truncated nature of each of these rights within the capitalist system. So, for example, he argues that 'liberty as a right of man is not founded upon relations between man and man, but rather upon separation of man from man. It is the right of such separation. The right of the circumscribed individual, withdrawn into himself.

In a similar vein, he argues that property is 'the right of self-interest' which 'leads every man to see in other men, not the realization but rather the limitation of his own liberty'. Equality, in this context, is merely the guarantee that 'every man is equally regarded as a self-sufficient monad', while security is the guarantee of each selfish, isolated individual's property. ${ }^{22}$ In light of this, Marx concludes that

\begin{abstract}
None of the supposed rights of man, therefore, go beyond the egoistic man, man as he is, as a member of civil society; that is, an individual separated from the community, withdrawn into himself, wholly preoccupied with his private interest and acting in accordance with his private caprice. Man is far from being considered, in the rights of man, as a species-being; on the contrary, species-life itself_-society-appears as a system which is external to the individual and as a limitation of his original independence. The only bond between men is natural necessity, need and private interest, the preservation of their property and their egoistic persons. ${ }^{23}$
\end{abstract}

\footnotetext{
20 'Political emancipation certainly represents a great progress. It is not, indeed, the final form of human emancipation, but it is the final form of human emancipation within the framework of the prevailing social order'. Marx (n 18) 35 [original emphasis].

21 ibid 42.

22 ibid 42-43.

23 ibid 43. Marx and Engels would, in later years, decry the narrow egotism and truncated freedom characteristic of life under capitalism in very similar terms: 'The bourgeoisie, wherever it has got the upper hand, has put an end to all feudal, patriarchal, idyllic relations. It has pitilessly torn asunder the motley feudal
} 
This is the version of the article accepted for publication in Human Rights Quarterly published by John Hopkins University Press: https://www.press.jhu.edu/journals/human-rights-quarterly

Accepted version downloaded from SOAS Research Online: http://eprints.soas.ac.uk/24788/

In sum Marx argues that the rights of man do not, in substance, reflect genuine human emancipation. Instead, while purporting to emancipate individuals they are, in fact, constitutive of a set of social relations that denies individuals the capacity to realise their true nature (species-being) as social beings. Real emancipation will only take place when the social relations of capitalism are transcended, and the distinctions between formal political freedom and action in the 'private' sphere are replaced by genuine community. ${ }^{24}$

Clearly, this critique of rights lends itself to the idea that Marx, and Marxists, can and should reject human rights. However, the important exposition of the limitations of rights that Marx undertook here is only part of the story. It must be remembered that the entire purpose of this intervention by Marx was to dispute the arguments of Bauer and to defend the claim that Jewish people in Germany should be granted equal citizenship, that is to say equal rights. ${ }^{25}$ Of course, the entire tenor of Marx's argument is that granting civil and political rights to Jewish people in Germany will not lead to their emancipationsubstantively - any more than it will or has done for any other group. In this sense, the essence of Marx's critique is that political emancipation 'is not the final and absolute form of buman emancipation'. ${ }^{26}$

With that said, he acknowledges that the limited form of political emancipation provided by the attainment of the rights of man 'certainly represents a great progress. It is not, indeed, the final form of human emancipation, but it is the final form of human emancipation within the framework of the prevailing social order. ${ }^{27}$ In light of this, On the

ties that bound man to his "natural superiors", and has left remaining no other nexus between man and man than naked self-interest, than callous "cash payment". It has drowned the most heavenly ecstasies of religious fervour, of chivalrous enthusiasm, of philistine sentimentalism, in the icy water of egotistical calculation. It has resolved personal worth into exchange value, and in place of the numberless indefeasible chartered freedoms, has set up that single, unconscionable freedom - Free Trade'. Karl Marx and Friedrich Engels, The Communist Manifesto (Penguin Books 1967) 222.

24 'Human emancipation will only be complete when the real, individual man has absorbed into himself the abstract citizen; when as an individual man, in his everyday life, in his work, and in his relationships, he has become a species-being; and when he has recognized and organized his own powers (forces propres) as social powers so that he no longer separates this social power from himself as political power'. ibid 46 [original emphasis].

${ }^{25}$ Justine Lacroix and Jean-Yves Pranchère, 'Karl Marx Fut-il Vraiment un Opposant Aux Droits de L'homme?' (2012) 62 Revue Française de Science Politique 433, 436.

${ }^{26}$ Marx (n 18) 32 [original emphasis].

27 ibid 35 . 
This is the version of the article accepted for publication in Human Rights Quarterly published by John Hopkins University Press: https://www.press.jhu.edu/journals/human-rights-quarterly

Accepted version downloaded from SOAS Research Online: http://eprints.soas.ac.uk/24788/

Jewish Question can definitely be seen as a cutting critique of the limitations of rights within capitalism, but hardly represents a complete rejection of human rights, as such.

A stronger, and apparently more clear cut, dismissal of rights can be found some years later in The German Ideology, which Marx co-authored with Friedrich Engels, and in which they argue that as 'far as law is concerned, we with many others have stressed the opposition of communism to law, both political and private, as also in its most general form as the rights of man'. ${ }^{28}$ While this unequivocal statement definitely tallies with the idea that Marx rejected bourgeois law and rights, ${ }^{29}$ it is not, as presented, part of a well thought out argument or theory. It stands, therefore, as more aphorism than analysis and, consequently, should not be read as dispositive. Later still, we see Marx again register his reservations about appeals to rights in his Critique of the Gotha Program..$^{30}$ Here, again, Marx criticises the limitations of 'bourgeois right' - in particular the inability of formal, legal equality to account for substantive real world differences between individuals and classes. ${ }^{31}$ This, in turn, means that the language of equality, and formal guarantees of equal right, in fact serve to conceal and entrench substantive inequality. ${ }^{32}$ Marx concludes his critique of the Gotha Program by dismissing the idea of equal rights as 'dogmas, ideas which in a certain period had some meaning but have now become obsolete verbal rubbish' and been reduced to mere 'ideological nonsense'. ${ }^{33}$

Though highly critical of the concept of right as used in the Gotha Program, Marx also acknowledges that right 'can never be higher than the economic structure of society and

\footnotetext{
${ }^{28}$ Karl Marx and Frederick Engels, Marx-Engels Collected Works: Volume 5 (Lawrence \& Wishart 2010) 209.

${ }^{29}$ Steven Lukes, 'Can a Marxist Believe in Human Rights?' (1981) 4 Praxis International 334, 338.

${ }^{30}$ Karl Marx, 'Critique of the Gotha Program' in Tucker (ed), The Marx-Engels Reader (2 ${ }^{\text {nd }}$ edn, W.W. Norton \& Co. 1978) 525.

${ }^{31}$ In this regard, Marx argues that 'equal right is an unequal right for unequal labor. It recognizes no class differences, because everyone is only a worker like everyone else; but it tacitly recognizes unequal individual endowment, and thus productive capacity, as a natural privilege. It is, therefore, a right of inequality, in its content, like every right. Right, by its very nature, can consist only in the application of an equal standard; but unequal individuals (and they would not be different individuals if they were not unequal) are measurable only by an equal standard insofar as they are brought under an equal point of view, are taken from one definite side only -- for instance, in the present case, are regarded only as workers and nothing more is seen in them, everything else being ignored. Further, one worker is married, another is not; one has more children than another, and so on and so forth. Thus, with an equal performance of labor, and hence an equal in the social consumption fund, one will in fact receive more than another, one will be richer than another, and so on. To avoid all these defects, right, instead of being equal, would have to be unequal'. ibid 530-531.

32 ibid 530.

33 ibid.
} 
This is the version of the article accepted for publication in Human Rights Quarterly published by John Hopkins University Press: https://www.press.jhu.edu/journals/human-rights-quarterly

Accepted version downloaded from SOAS Research Online: http://eprints.soas.ac.uk/24788/

its cultural development conditioned thereby, ${ }^{34}$ or, in other words, that equal rights, as such, can never challenge the inherent inequalities produced by the capitalist system. Marx concludes by noting that only when capitalism is transcended and a truly new form of society has begun to consolidate itself 'can the narrow horizon of bourgeois right be crossed in its entirety and society inscribe on its banner: From each according to his ability, to each according to his needs!. ${ }^{35}$ As with On the Jewish Question, Marx could be read here as rejecting rights, or, he can be seen as engaging in a thorough and necessary critique of blind faith in rights. Bringing to the fore the ways in which the unfreedom produced by capitalism structurally and necessarily frustrates the high ideals contained in appeals to human rights, ${ }^{36}$ without necessarily constituting a rejection of rights tout court.

This latter interpretation gains credence from the fact that throughout their lives both Marx and Engels, while entertaining no illusions on the matter, wrote repeatedly in defence of the rights to free expression, protest and the right to vote. From an early age Marx was an ardent critic of censorship, and defender of freedom of expression. For example, in 1842 he wrote in opposition to a proposed Prussian censorship law on the basis that 'censorship is a permanent attack on the rights of private persons, and still more on ideas'. ${ }^{37}$ At a later stage, commenting on the Paris Commune of 1871, Marx registered a powerful defence of the right to universal suffrage, ${ }^{38}$ while Engels wrote on a number of occasions decrying inroads on the right to protest in England, a right which he considered to be 'one of the most precious rights of ... working people', which ought to be defended at all costs. $^{39}$

\footnotetext{
34 ibid 531.

35 ibid.

36 As Roth notes, the 'relentless theme of Marx's critique of liberal accomplishments is that these fail to overcome the underlying conditions that at once necessitate them and render largely illusory their benefits for the subordinate class'. Brad Roth, 'Retrieving Marx for the Human Rights Project' (2004) 17 Leiden Journal of International Law 31, 38.

${ }^{37}$ Karl Marx and Frederick Engels, Marx-Engels Collected Works: Volume 1 (Lawrence \& Wishart 2010) 168; and see: 'The Prussian Press Bill' in Karl Marx, The Revolutions of 1848: Political Writings Volume 1 (Verso 2010) 134.

38 Instead of deciding once in three or six years which member of the ruling class was to misrepresent the people in Parliament, universal suffrage was to serve the people, constituted in Communes ... nothing could be more foreign to the spirit of the Commune than to supersede universal suffrage by hierarchical investiture'. Karl Marx, The First International and After: Political Writings Volume 3 (Verso 2010) 210-211.

${ }^{39}$ Karl Marx and Frederick Engels, Marx-Engels Collected Works: Volume 23 (Lawrence \& Wishart 2010) 295.
} 
This is the version of the article accepted for publication in Human Rights Quarterly published by John Hopkins University Press: https://www.press.jhu.edu/journals/human-rights-quarterly

Accepted version downloaded from SOAS Research Online: http://eprints.soas.ac.uk/24788/

Alongside these defences of rights in concrete instances, Marx, in his inaugural address to the International Workingman's Association (the First International), invoked, in glowing terms, the struggle of the English working class for the Ten Hours Bill, ${ }^{40}$ noting that

This struggle about the legal restriction of the hours of labor raged the more fiercely since, apart from frightened avarice, it told indeed upon the great contest between the blind rule of the supply and demand laws which form the political economy of the middle class, and social production controlled by social foresight, which forms the political economy of the working class. Hence the Ten Hours' Bill was not only a great practical success; it was the victory of a principle; it was the first time that in broad daylight the political economy of the middle class succumbed to the political economy of the working class. ${ }^{41}$

Later, in Capital, Marx returns to the struggle for the Ten Hour Bill, noting. approvingly, that in "place of the pompous catalogue of the "inalienable rights of man" there steps the modest Magna Carta of the legally limited working day, which at last makes clear "when the time which the worker sells is ended, and when his own begins"". ${ }^{42}$

Significantly, the Provisional Rules of the First International, which Marx also wrote, begins with the affirmation that 'the struggle for the emancipation of the working classes means not a struggle for class privileges and monopolies, but for equal rights and duties, and the abolition of all class rule,. ${ }^{43}$ The Rules further 'hold it the duty of a man to claim the rights of a man and a citizen, not only for himself, but for every man who does his duty'. ${ }^{44}$ Clearly, then, Marx's stated views on rights throughout his life can best be described as 'critical, differentiated, underdeveloped and, in more than a few instances, ambiguous'. ${ }^{45}$ All of which is to say that while Marx was certainly critical of human rights as lauded, liberal abstractions, he was also aware of their value and importance in political struggles to advance the interests of the working class. Nonetheless, the inconsistency in his statements on the matter led to important debates within the Marxist tradition about how human rights should be approached, and it is to these debates that we now turn.

\section{ii. Can a Marxist Support Human Rights?}

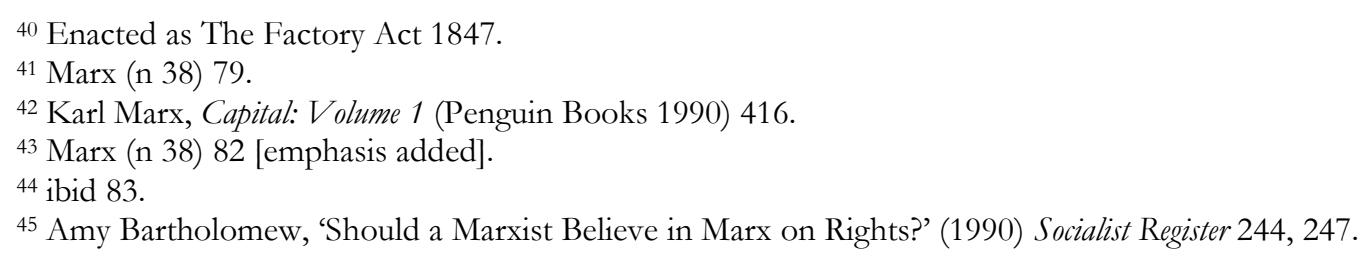


This is the version of the article accepted for publication in Human Rights Quarterly published by John Hopkins University Press: https://www.press.jhu.edu/journals/human-rights-quarterly

Accepted version downloaded from SOAS Research Online: http://eprints.soas.ac.uk/24788/

Following Marx's death, the issue of human rights received relatively scant attention within the international socialist movements which his work inspired. The focus throughout the late nineteenth and early twentieth centuries being, rather, on issues of economic theory, party building and social revolution. ${ }^{46}$ However, in the early 1980s Steven Lukes reinvigorated the debate by asking whether Marxists could, consistent with what he termed 'the central doctrines essential to the Marxist canon', believe in human rights. ${ }^{47}$ Lukes intervention was prompted by the bourgeoning popularity of human rights, 'particularly in evidence on the left, and within the left, among Marxists'. ${ }^{48}$

To answer the question, Lukes engaged in a survey of the statements of Marx, Engels, Lenin and others on questions of rights and law. From this he concluded that 'Marx and Engels always wrote disparagingly about the language of rights and justice'. ${ }^{49}$ Added to this, and at a deeper level, Lukes argued that for Marx and subsequent Marxists, human rights are intolerable because they are inherently ideological, stabilizing class societies and concealing class interests ${ }^{50}$ Consequently, for Lukes, it is not possible for Marxists to believe in human rights. ${ }^{51}$ The language of belief adopted by Lukes is somewhat problematic, but the key point, in essence, is that, for him, it is not possible for Marxists to support human rights, and this is a view that was promptly contested.

Critical reaction to Lukes argument was immediate: Drucilla Cornell pointed out that, as shown above, it was inaccurate to say that Marx and Engels had only ever written disparagingly of rights, as Lukes claimed. Instead, Cornell noted that 'there are contradictory strains in Marx's own attitude to legality', and as such there was room for differing interpretations. ${ }^{52}$ She further argued that Lukes had misunderstood Marx's methodological approach to the question

\footnotetext{
46 Perry Anderson, Considerations on Western Marxism (Verso 1979) 44-45.

${ }^{47}$ Lukes (n 29) 335.

48 ibid 335.

49 ibid 338 .

50 ibid.

51 ibid 344. Since the publication of this article, Lukes has made, broadly, the same argument on several occasions: 'Marxism and Morality: Reflections on the Revolution of 1989' (1990) 4 Ethics \& International Affairs 19; 'On the Moral Blindness of Communism' (2001) 2(2) Human Rights Review 113; and 'Marxism and Morals Today' (2015) 24(1) New Labor Forum 54.

52 Drucilla Cornell, 'Should a Marxist Believe in Rights?' (1984) 4 Praxis International 45, 45.
} 
This is the version of the article accepted for publication in Human Rights Quarterly published by John Hopkins University Press: https://www.press.jhu.edu/journals/human-rights-quarterly

Accepted version downloaded from SOAS Research Online: http://eprints.soas.ac.uk/24788/

According to Marx, the State represents the distorted reality of civil society. What has been actualized in the modern State is the contradiction between the abstract freedom of civil society and the true freedom of a fully emancipated citizenry. The resolution of the contradiction awaits a change in social reality, a change which Marx believed would be brought about by the class whose life graphically denied the purported reconciliation of substantive and abstract freedom in the State ... Marx does not pit substantive freedom against the emptiness of formal right on the basis of what ought to be. The entire body of his work is devoted to showing that the contradiction between substantive and formal freedom is immanent in the nature of capitalist society itself..$^{53}$

Cornell concludes that it is only because Lukes has not understood Marx's dialectical method in his critique of bourgeois right that he 'fails to see how a belief in right can be reconciled with a politically sound interpretation of Marxism'.54

In his response to Lukes, William McBride argued that while Marx fully understood, and identified, 'the severe limitations of rights-talk' this 'does not preclude, logically speaking, either our resorting, within the Marxian tradition, to the language of rights in order to point up inconsistencies of practice in the sense of violations of asserted rights which abound within our present socio-economic-legal system, or our denominating certain fundamental particular practices of this system, even when they are consistently followed, as being wrong ${ }^{55}$ For McBride a Marxist could, thus, adopt or embrace some notion of human rights, so long as 'one maintains a critical recognition of the ideological uses to which rights talk has traditionally been put'. ${ }^{56}$

Finally, in response to Lukes, Amy Bartholomew argued that 'by relying on Marx's understanding of, and commitment to, the development of "rich individuality" and selfdevelopment entailed in the notion of "human emancipation" ... a basis may be found in Marx's work in which to ground a positive commitment to rights'. ${ }^{57}$ Expanding on this point, she argues that

\footnotetext{
53 ibid 48.

54 ibid 54

55 William McBride, 'Rights and the Marxian Tradition' (1984) 4 Praxis International 57, 70 [original emphasis]. 56 ibid 70.

${ }^{57}$ Bartholomew (n 45) 246; and see Fromm (n 16). As Nancy Fraser argues: 'individuality is a double-edged sword. On the one hand, it is a mark of personhood and intrinsic value ... On the other hand, it is easily made into a ruse of power, an instrument of domination. When divorced from a structural understanding of an exploitative social order, individuality can become a cult object, a substitute for critical thinking and an impediment to overcoming injustice'. Nancy Fraser, 'On Justice' (2012) 74 New Left Review 41, 48.
} 
While many existing rights may also encourage atomism and egoism, this is not a characteristic which is naturally and necessarily inscribed into their status as rights, or even as individual rights. Rather, the content and cultural meaning of a right may best be understood as the crystallization of past victories and defeats. The extent to which a right expresses and reinforces one rather than another form of individualism depends on the struggles and demands that are, and have been, made around, within and through it. $^{58}$

For these authors, then, there is ample scope within the Marxist tradition to argue for and defend human rights. Or, as Brad Roth puts it, for a 'human rights friendly reading of Marx [which] is both available and edifying'. ${ }^{59}$ Any such invocation of human rights must, however, pay close attention to the contradictory and problematic role that the language of human rights plays in the maintenance of the extant social order, and to the centrality of social struggle in framing human rights.

\section{iii. Should a Marxist Support Human Rights?}

If the foregoing establishes that, consistent with the Marxist tradition, one can support human rights, it still leaves open the strategic question as to whether one should. In this regard McBride, while responding to Lukes, argued forcefully that the 'outright rejection of human rights' would be 'a practical blunder within the context of contemporary politics' ${ }^{60}$ Effectively, McBride's view was that while capitalism remained the dominant and unchallenged system, and prospects for moving beyond it seemed slim, human rights represented important gains that Marxists and others should defend. ${ }^{61}$ Others argued that the failed experience of the Soviet Union provided a stark lesson as to why Marxists should embrace and defend human rights. As Cornell put it, the painful experience 'with the reality of a society which ... purportedly transcended legality has ... taught us about the continuing need for the institutionalization of right'. ${ }^{62}$

\footnotetext{
58 ibid 255.

${ }^{59}$ Roth (n 36) 32.

60 McBride (n 55) 57.

${ }^{61}$ As he put it, at 'the present stage of history, when a worldwide society of associated producers, in which the apparatuses of the state and of legal systems will have fallen into desuetude because of their no longer being needed, remains an exceedingly distant dream, it would be very short-sighted to deny that certain features of law can sometimes result in very progressive social outcomes'. ibid 71.

${ }^{62}$ Cornell (n 52) 46. In a similar vein, Alan Hunt argues that 'civil liberties, human rights and the rule of law (legal mechanisms and devices developed within capitalist societies) are essential preconditions of a defensible socialism'. Hunt (n 16) 105.
} 
This is the version of the article accepted for publication in Human Rights Quarterly published by John Hopkins University Press: https://www.press.jhu.edu/journals/human-rights-quarterly

Accepted version downloaded from SOAS Research Online: http://eprints.soas.ac.uk/24788/

Similar arguments have been made in recent years. Prabhat Patnaik, for example, argues forcefully that socialists and Marxists should support a 'rights based approach' to development. ${ }^{63}$ Patnaik places significant emphasis on pushing for the recognition of welfare, or socio-economic, rights because the recognition of such rights fundamentally questions capitalist social relations. For Patnaik, the recognition of such rights can form part 'of a series of measures that constitute a dialectics of subversion of the logic of capital' ${ }^{64}$ Conscious of Marx' oft-cited critiques of rights, Patnaik asks how can Marxists justify the adoption of a rights promoting strategy, and his answer is twofold:

\begin{abstract}
first, just as "democracy" in a bourgeois society serves to camouflage exploitation, just as "equality" in a bourgeois society is only the equality of commodity-owners in the marketplace, underlying which is the reality of exploitation, likewise "rights" in a bourgeois society are meant only to sustain a structure of exploitation. But this does not make "rights" meaningless, no more than it makes "democracy" or "equality" meaningless. On the contrary, just as "democracy" and "equality" can get realised only in a society transcending capitalism, i.e., in a socialist society, likewise "rights" too become meaningful only in a socialist society, which is why the left must struggle over "rights" in a bourgeois society, as it struggles over "democracy" and "equality". Bourgeois society's "hypocrisy" over rights therefore, far from robbing the concept of legitimacy, makes it an important transitional demand for the left. ${ }^{65}$
\end{abstract}

Patnaik's argument, then, is that in the contemporary global order, Marxists both can and should support human rights claims, notwithstanding the very real limitations of and problems with the language of human rights.

Similar arguments are advanced by Robin Blackburn. In a piece discussing the origins of of human rights, he argues that 'the abuse of human rights for great-power ends need not necessarily disqualify them as emancipatory tools' ${ }^{66}$ Expanding on this, he argues that notwithstanding the latter-day militarist and imperialist instrumentalisation of human rights discourse by Washington and its allies', human rights 'cannot be written off. ${ }^{67}$ As he puts it

\footnotetext{
${ }^{63}$ Prabhat Patnaik, 'A Left Approach to Development' (2010) 45 (30) Economic \& Political Weekly 33.

64 ibid 35.

65 ibid 36-37.

${ }^{66}$ Robin Blackburn, 'Reclaiming Human Rights' (2011) 69 New Left Review 126, 130.

67 ibid 136.
} 
Just as the 'rights of man' or abolitionist demands were sometimes misappropriated in past centuries, so 'humanitarianism' has all too often been adopted as cover for post-Cold War militarism in recent times. It is necessary to disentangle the different uses of human rights and to register that cynical attempts to exploit its language are likely to backfire. If the discourse of human rights had never been more than diplomatic jargon, it would not have become hegemonic; and if it does end up being no more than such a jargon, it will have lost its hegemony. In practice, the language of rights is used to attract and maintain a following. Those who wage imperial wars in its name are adopting a risky strategy that can blow up in their faces. Equally obviously, movements of protest against torture, arbitrary arrest, imprisonment are desperately needed in many parts of the world. Those attacking the US or British governments for 'rendition' and the torture of suspects, or those claiming labour rights in China, find succour in human-rights language even if they would also need to reach beyond it. ${ }^{68}$

In sum, then, Blackburn, like Patnaik, adopts a stance of 'uncompromising realism' as Perry Anderson terms it. ${ }^{69}$ A position which can 'support any local movements or limited reforms, without pretending that they alter the nature of the system' ${ }^{70}$

This is recognition that while human rights are routinely mobilised to protect and maintain the status quo, they are at the same time 'emancipatory tools' that can be directed against that same status quo. Blackburn concludes that human rights

can serve as a valuable watchword and measure. But because inequality and injustice are structural, constituted by multiple intersecting planes of capitalist accumulation and realization, more needs to be said-especially in relation to financial and corporate power and how these might be curbed and socialized. The plight of billions can be represented as a lack of effective rights, but it is the 'property question' - the fact that the world is owned by a tiny elite of expropriators - that is constitutive of that plight. The slogan of rights takes us some way along the path; but it alone cannot pose the property question relevant to the 21 st century. ${ }^{71}$

In this way Blackburn echoes Marx's fundamental critique of rights: which is to say that they cannot be realised, in any meaningful sense, under capitalism. However, in tune with

\footnotetext{
68 ibid.

${ }^{69}$ Perry Anderson, 'Renewals' (2000) 1 New Left Review 1, 10.

70 ibid.

${ }^{71}$ Blackburn (n 66) 137-138.
} 
This is the version of the article accepted for publication in Human Rights Quarterly published by John Hopkins University Press: https://www.press.jhu.edu/journals/human-rights-quarterly

Accepted version downloaded from SOAS Research Online: http://eprints.soas.ac.uk/24788/

Bartholomew and others, he recognises the important role human rights can play in social and political struggles, and how these struggles, in turn, can transform understandings of human rights. There is, therefore, ample scope within the Marxist tradition for a critical embrace of human rights, in the next section with look at the insights and limitations from other critical accounts of human rights.

\section{CRITIQUES OF RIGHTS}

In an important recent article, Robin West bemoans what she sees as the disappearance of the radical critique of rights. As she puts it the 'rights critique has ... virtually disappeared from contemporary legal scholarship and pedagogy. We do not hear much, if anything, of rights' wrongs anymore - of their subordinating, legitimating, and alienating effects'. ${ }^{72}$ West raises an important issue, and her concern carries much weight in the US context, where many of the erstwhile radical critics of liberal rights, have either abandoned their project or, to one degree or another, become grudging advocates of rights. However, West's more general contention is unfounded, as the critique of rights is alive and well. In large part because of their now hegemonic position, and because of their use to justify and legitimate all manner of imperial depredations, the language of rights continues to come in for considerable critique across the broad 'left'. It is now, in certain circles, in vogue to be 'against, ${ }^{73}$ or to dismiss human rights. ${ }^{74}$ Here we will consider the arguments in these radical critiques of rights, starting with a brief overview of the Critical Legal Studies critique of the 1980s, before going on to look at the more recent iterations, and then concluding this section by sounding some reservations about the value of these critiques.

\section{i. Critical Legal Studies and the Critique of Rights}

In the early 1980s the Critical Legal Studies (CLS) movement engaged in a sustained critique of the concept of rights. ${ }^{75}$ Some of the key aspects of the various CLS critiques were that rights, and rights talk, tended: (i) to insulate and valorise subordination in the private sphere, (ii) to legitimate, perpetuate and conceal greater injustice than they

\footnotetext{
${ }^{72}$ Robin West, 'Tragic Rights: The Rights Critique in the Age of Obama' (2011) 53 William and Mary Law Review $713,714$.

${ }^{73}$ Zizek (n 10).

${ }^{74}$ Martti Koskenniemi, 'Human Rights Mainstreaming as a Strategy for Institutional Power' (2010) 1 Humanity 47.

${ }^{75}$ For useful overviews of the CLS movement, see: Roberto Mangabeira Unger, The Critical Legal Studies Movement (Verso 2015); and Alan Hunt, 'The Theory of Critical Legal Studies' (1986) 6 Oxford Journal of Legal Studies 1.
} 
This is the version of the article accepted for publication in Human Rights Quarterly published by John Hopkins University Press: https://www.press.jhu.edu/journals/human-rights-quarterly

Accepted version downloaded from SOAS Research Online: http://eprints.soas.ac.uk/24788/

addressed and (iii) that the language of rights tended to be atomistic and to alienate people from one another. ${ }^{76} \mathrm{~A}$ further, central element of the CLS critique was that human rights, as with all legal discourse, were inherently indeterminate. All of this stemmed from a 'loss of faith in rights' on the part of sections of the American left. ${ }^{77}$

The first of these concerns is captured well by Peter Gabel and Paul Harris's insistence that 'the expansion of legal rights has only a limited impact on people's real lives, and ... even these limited gains can be wiped out by a change in the political climate. ${ }^{78}$ The basic idea being that the formal recognition of rights, as such, does not lead to the fundamental material change in people's wellbeing that naïve, liberal belief in rights implies. In this way, the formal recognition of rights in the public sphere can, and often does, leave untouched unequal relations of power in 'civil society'. ${ }^{79}$ The second major critique is well captured by West, who argues that rights do harm because 'they distract our critical gaze, thereby legitimizing larger injustices'. ${ }^{80}$ Or, in other words, that a preoccupation with rights distracts us from addressing deeper, structural issues of inequality and injustice.

With respect to the atomising character of rights discourse, Gabel and Harris argue forcefully that 'an excessive preoccupation with "rights consciousness" tends in the long run to reinforce alienation and powerlessness, because the appeal to rights inherently affirms that the source of social power resides in the State rather than in the people themselves. ${ }^{81}$ In other words, the language of rights reinforces an ideology and sense of self that, ultimately, serves to sustain the extant social order. Finally, with respect to the notion of indeterminacy, perhaps the most significant contribution of CLS, Morton Horowitz notes that the inherent tension in liberal rights discourse between commitment to subjective normative values and the attempt to present rights in objective, neutral, terms has led to 'an ungrounded conception of rights that allows anyone to propose his or her favourite right. Thus, it seems to be part of the indeterminate nature of rights discourse

\footnotetext{
76 West (n 72) 716.

${ }^{77}$ Duncan Kennedy, 'The Critique of Rights in Critical Legal Studies' in Brown and Halley (eds.), Left Legalism/Left Critique (Duke University Press 2002) 178, 179.

${ }^{78}$ Peter Gabel and Paul Harris, 'Building Power and Breaking Images: Critical Legal Theory and the Practice of Law' (1982-83) 11 New York. University Review of Law and Social Change 369, 369.

${ }^{79}$ See, also, Mark Tushnet, 'The Critique of Rights' (1993) 47 Southern Methodist University Law Review 23.

${ }^{80}$ West (n 72) 721.A similar 'displacement thesis' is advanced by Wendy Brown and others, see: Wendy Brown, “The Most We Can Hope For ...”: Human Rights and the Politics of Fatalism” (2004) 103 South Atlantic Quarterly 451, 461-462.

${ }^{81}$ Gabel and Harris (n 78) 375.
} 
This is the version of the article accepted for publication in Human Rights Quarterly published by John Hopkins University Press: https://www.press.jhu.edu/journals/human-rights-quarterly

Accepted version downloaded from SOAS Research Online: http://eprints.soas.ac.uk/24788/

that it can be deployed with equal logic to protect the existing structure of privilege as well as to challenge and legitimate that structure'. ${ }^{82}$

\section{ii. The Critique of Rights Today}

These, then, were the main lines of the CLS critique of human rights developed in the 1980s. For a variety of reasons, among which we could number the fall of the Berlin Wall and the triumph (in the forms of Clinton and Blair) of Third Way liberalism, these critiques of rights did fall somewhat out of fashion. However, following the election of George W. Bush as president of the US and the illegal US-led invasion of Iraq, a new wave of human rights critiques emerged. One prominent account was articulated by David Kennedy, who argued, following in the CLS tradition, that

Even very broad social movements of emancipation-for women, for minorities of various sorts, for the poor-have their vision blinkered by the promise of recognition in the vocabulary and institutional apparatus of human rights. They will be led away from the economy and toward the state, away from political/social conditions and toward the forms of legal recognition. ${ }^{83}$

For this and other reasons, Kennedy concluded, reluctantly, that human rights and the extant 'human rights movement', might, on balance, be 'more a part of the problem in today's world than part of the solution'. ${ }^{84}$

Similar misgivings about human rights have been expressed by another prominent international lawyer, Martti Koskenniemi; for him, one of the fundamental problems with human rights is that it is a language which can be mobilised by both sides in any given dispute or argument. ${ }^{85}$ As a result the value of human rights language in effecting

\footnotetext{
82 Morton Horwitz, 'Rights' (1988) 23 Harvard Civil Rights-Civil Liberties Law Review 393, 399. In a similar vein Makau Mutua argues that Makau Mutua argues the language of human rights ... is fraught with limitations which could be detrimental to the project of transforming deeply distorted societies. Inherent in the language of rights are indeterminacy, elasticity, and the double-edged nature of the rights discourse. All these characteristics open the rights language to malleability, misuse by malignant social elements, and make then a tool in the hands of those opposed to reform'; Makau Mutua, 'Human Rights and Powerlessness: Pathologies of Choice and Substance' (2008) 56 Buffalo Law Review 1027, 1028.

${ }^{83}$ David Kennedy, 'The International Human Rights Movement: Part of the Problem' (2002) 15 Harvard Human Rights Journal 101, 110.

84 ibid 101. The argument, with some revisions, is reiterated in: David Kenned, 'The International Human Rights Regime: Still Part of the Problem?' in Dickinson, Katselli, Murray and Pedersen (eds), Examining Critical Perspectives on Human Rights (CUP 2012) 19.

${ }^{85}$ Koskenniemi (n 74) 49-50.
} 
This is the version of the article accepted for publication in Human Rights Quarterly published by John Hopkins University Press: https://www.press.jhu.edu/journals/human-rights-quarterly

Accepted version downloaded from SOAS Research Online: http://eprints.soas.ac.uk/24788/

meaningful change is undermined and, for Koskenniemi, individuals and movements should look to other languages, such as economics, to advance their causes. ${ }^{86}$ With Kennedy and Koskenniemi we have a restatement of key elements of the earlier CLS critique: namely that rights are indeterminate, and do not touch the real, material causes of injustice and inequality. From Wendy Brown, and others, we also get a restatement of the idea that human rights are problematic because they entrench forms of individuality and subjectivity which, on balance, tend to sustain the status quo. ${ }^{87}$ Likewise, Zizek and others argue that the language of human rights mainly provides an ideological apologia for Western imperial interventions around the world. ${ }^{88}$ In this way, 'human rights practice essentially results in both the reproduction and strengthening of the very state-governing apparatuses it confronts, and as a result ultimately undermines its own aims ${ }^{89}$ From all of this, it follows, that movements for fundamental social change should be sceptical of and eschew the language of human rights, and instead should focus on other emancipatory discourses.

\section{iii. The Limits of Critique}

The first thing that needs to be said about these critical accounts of human rights is that they raise crucially important and valid critiques of dominant liberal discourses of human rights. With that said, these critiques also fall short in several important ways. Three of the main shortcomings in these critiques are: (i) the overemphasis on the dominant narrative of human rights; (ii) the idealistic nature of the critiques (in the sense that they are, in the first instance, an engagement with and critique of ideas and concepts in the abstract) and (iii) the divorce of this critique from concrete struggles. Each of these shortcomings, more pronounced in some cases than others, reduces these critical accounts to a sort of radical quietism; a stance which decries the extant order, without conceiving or countenancing any meaningful alternative.

The indeterminacy critique, highlighting the atavistic forms of individuality at the heart of mainstream accounts of human rights and the cynical deployment of human rights to

\footnotetext{
$86 \mathrm{ibid}$

${ }^{87}$ See Brown (n 80) and Wendy Brown, 'Suffering Rights as Paradoxes' (2000) 7 Constellations 230.

88 'what the "human rights of the Third World suffering victims" effectively means today, in the predominant discourse, is the right of Western powers themselves to intervene politically, economically, culturally and militarily in the Third World countries of their choice, in the name of defending human rights'. Zizek (n 10) 128.

${ }^{89}$ Jarret Zigon, 'Human Rights as Moral Progress? A Critique' (2013) 28 Cultural Anthropology 716, 719.
} 
This is the version of the article accepted for publication in Human Rights Quarterly published by John Hopkins University Press: https://www.press.jhu.edu/journals/human-rights-quarterly

Accepted version downloaded from SOAS Research Online: http://eprints.soas.ac.uk/24788/

justify imperialist depredations are all valid. The problem, however, is when these legitimate critiques of liberal/dominant rights discourses evolve into a rejection of rights as such. It is undeniable, as Blackburn puts it, that human rights are cynically deployed for 'great-power ends', ${ }^{90}$ that liberal rights discourse entrenches a truncated form of individuality, ${ }^{91}$ and that rights are not the neutral, determinate rules that liberal legalism pretends to. ${ }^{92}$ All of this, however, merely demonstrates the inaccuracy of the selfperception of dominant human rights discourses, and says little or nothing about how movements striving for fundamental social change can or should engage with the language and concept of rights as such.

Tied to this one-sidedness is the idealistic character of these rights critiques. In a rather scathing manor, Anthony Chase highlighted this shortcoming in the context of the first wave CLS critique of rights in the 1980s. As Chase sardonically put it

Nothing is more striking about the literary criticism approach than the unwillingness or inability of its practitioners to provide concrete historical and sociological studies of instances where the "self-confidence" or "selfactivity" of radical social movements (whether in the Americas, Europe, Africa, Asia, or the Middle East) have actually been "crushed", not by arduous working conditions or impoverization, not by the inability of civil society to impose civil rights and liberties against state power, not by police surveillance or death squads, not by famine or inadequate public health services, not by the dull necessity of economic reproduction, not by armed invasions, prison and torture cells, or "surgical air strikes" against villages and cities, but, rather extraordinarily, by the central target of CLS critique: appellate judicial reasoning in the liberal mode. The enormous emphasis upon and exclusive focus given to the rhetoric of judges in (apparently) maintaining empires, civilizations, and the fabric of societies, has made CLS a unique form of social theory (if one may call it that), in existence hardly anywhere outside of the cloistered legal academy. ${ }^{93}$

Though caustic, Chase's insight is valid and important. It is not the language of human rights that sustains the extant social order, though it can and does play a part in the broader ideological apparatus, but an array of material relationships. Critiques of rights in the broad

\footnotetext{
${ }^{90}$ Blackburn (n 66) 130.

${ }^{91}$ C.B. Macpherson, The Political Theory of Possessive Individualism (OUP 1962).

${ }^{92}$ See David Kairys, 'Introduction' in Kairys (ed), The Politics of Law: A Progressive Critique (3rd edn, Basic Books 1998) 1.

93 Anthony Chase, 'A Note on the Aporias of Critical Constitutionalism' (1987) 36 Buffalo Law Review 403, 406-407.
} 
This is the version of the article accepted for publication in Human Rights Quarterly published by John Hopkins University Press: https://www.press.jhu.edu/journals/human-rights-quarterly

Accepted version downloaded from SOAS Research Online: http://eprints.soas.ac.uk/24788/

CLS tradition routinely lose sight of this, and become trapped in a hall of mirrors where the enemy is a discourse, rather than the material relationships that structure discourses one way or another. ${ }^{94}$

Finally, then, these critiques are lacking because they are divorced from concrete struggles and the ideas which animate such struggles. So, for example, it is true to say that rights can have myriad different meanings in the abstract, but in concrete cases they are given a specific meaning. This meaning is fought over and determined in and through social struggles, which sometimes make their way to the rarefied environs of the courtroom, but are not limited to this. The critique of rights, in the abstract, loses much of its veracity and efficacy when the messiness of political and social struggles have to be accounted for. One way, then, in which the shortcomings of human rights, rightly highlighted by these critiques, can be addressed, is through embracing a substantive political or social vision of change. As Morton Horwitz argued, the 'most promising way to ensure that rights may be used on behalf of the socially weak, and to mitigate ... undesirable long-term risks of rights conceptions, is to ground rights theory in a substantive conception of the good society'. ${ }^{95}$

In a similar vein, Karl Klare, reflecting on the CLS tradition after the collapse of the Berlin Wall, argued that perhaps 'the best conclusion is that rights discourse needs to be transformed, not abandoned; that its individualism should be tempered by an infusion of communitarian and egalitarian values; and that rights discourse must be made more sensitive to issues of gender and cultural difference'. ${ }^{96}$ Divorced from concrete struggles and visions of an alternative world, critiques of rights end up accepting, much like the theories they critique, the extant, capitalist order as their perennial premise. ${ }^{97}$ In the next

\footnotetext{
94 '[Neither] thoughts nor language in themselves form a realm of their own ... they are only manifestations of actual life'. Karl Marx and Friedrich Engels, The German Ideology (Lawrence \& Wishart 1970) 118 [original emphasis].

${ }^{95}$ Horwitz (n 82) 404. A similar point is made by Karl Klare, who argues that 'by itself rights discourse does not and probably cannot provide us with the criteria for deciding between conflicting claims of right. In order to resolve rights conflicts, it is necessary to step outside the discourse. One must appeal to more concrete and therefore more controversial analyses of the relevant social and institutional contexts than rights discourse offers; and one must develop and elaborate conceptions of and institutions about human freedom and self-determination by reference to which one seeks to assess rights claims and resolve rights conflicts'. Karl Klare, 'Legal Theory and Democratic Reconstruction: Reflections on 1989' (1991) 25 University of British Columbia Law Review 69, 101.

${ }^{96}$ Klare (n 96) 97.

${ }^{97}$ As Wood puts it: 'The whole debate on rights today takes capitalist conditions for granted, as if they were the inevitable, natural order of things, whether we like it or not'. Ellen Meiksins Wood, 'Capitalism and Social Rights' (2009) 24(2) Against The Current 28, 29.
} 
This is the version of the article accepted for publication in Human Rights Quarterly published by John Hopkins University Press: https://www.press.jhu.edu/journals/human-rights-quarterly

Accepted version downloaded from SOAS Research Online: http://eprints.soas.ac.uk/24788/

section, we will see how, by shifting our understanding of rights and situating it within the broader, emancipatory theory of Marxism, it is possible to mobilise the language of rights without succumbing to the siren call of liberal legalism.

\section{Human Rights, CAPitAlism AND the StRuggle For Democracy}

Two key points emerge from the foregoing. First, within the broad Marxist tradition there is scope to defend and mobilise the language of human right. Second, though critiques of human rights abound, these critiques are limited and do not speak to the concrete struggles that exploited and subordinate groups around the world are engaged in today. Following on from this, the rest of this article is devoted to providing the tentative outlines of a way of approaching human rights from within the Marxist tradition. It is an approach that gives priority to three key principles: (i) recognition that the causes of what we see as human rights violations around the world today are structurally embedded in the system of global capitalism; (ii) from a methodological perspective, understanding the nature of contradiction in social phenomena, and for present purposes in relation to human rights; and (iii) the centrality of social and political struggles for determining the meaning and content of rights in particular contexts.

On the first point, it is not possible in a single article to fully unpack this, but there is ample literature available, ${ }^{98}$ to demonstrate, as Thomas Pogge has argued, that the structures created by neoliberal globalisation have produced 'a supranational institutional regime that foreseeably produces massive and reasonably avoidable human rights deficits'. ${ }^{99}$ In myriad ways the system of global capitalism reproduces itself in ways that undermine the entire corpus of human rights. This, in turn, means that discreet campaigns and struggles around specific rights issues are also, sometimes more clearly than others, struggles against the extant system. It also means that, long-term, the meaningful attainment of human rights will require transcending the extant system. Accepting this as a major premise, the next three sections set out some methodological points about how we should approach human

\footnotetext{
98 See: Samir Amin, Capitalism in the Age of Globalization (Zed Books 2014); William Robinson, Global Capitalism and the Crisis of Humanity (CUP 2014); Anwar Shaikh, Capitalism: Competition, Conflict, Crises (OUP 2016); John Smith, Imperialism in the Twenty-First Century: Globalization, Super-Exploitation, and Capitalism's Final Crisis (Monthly Review Press 2016); Wolfgang Streeck, How Will Capitalism End? (Verso 2016); and Michael Yates, The Great Inequality (Routledge 2016).

${ }_{99}$ Thomas Pogge, 'Are We Violating the Human Rights of the World's Poor?’ (2011) 14 Yale Human Rights \& Development Law Journal 1, 20. See also: Susan Marks, 'Human Rights and Root Causes’ (2011) 74 Modern Law Review 57.
} 
This is the version of the article accepted for publication in Human Rights Quarterly published by John Hopkins University Press: https://www.press.jhu.edu/journals/human-rights-quarterly

Accepted version downloaded from SOAS Research Online: http://eprints.soas.ac.uk/24788/

rights, and looks at two, broad, contexts in which embracing human rights can be part of challenging the overall system.

\section{i. The Future in the Present: Rights, Struggle and Contradiction}

Implicit in critiques of human rights, and explicit in some cases, is the idea that the language of human rights should be jettisoned, and projects of emancipatory politics advanced through some other, presumably less compromised, language. The problem with this, as Patnaik pointed out above, is that under capitalism, every conceivable discourse will be compromised and limited by dint of the conditions under which it must be deployed. Under capitalism, as Marx pointed out, the language of rights will necessarily fall short of its grand promise. But, there is no reference point outside of capitalism from which we can begin to construct alternatives to it. As David Harvey notes, change 'arises out of an existing state of affairs and it has to harness the possibilities immanent within the existing situation'. ${ }^{100}$ In a similar vein, Terry Eagleton argues that emancipatory politics 'inserts the thin end of the wedge of the future into the heart of the present'. ${ }^{101}$ But, of course, this future can only begin to be built in the present, a 'different future has to be the future of this particular present. And most of the present is made up of the past. We have nothing with which to fashion a future other than the few, inadequate tools we have inherited from history'. ${ }^{102}$

Human rights are one of the key 'inadequate tools' we have at our disposal today. In mobilising human rights we have to be conscious of the contradictory nature of human rights, and of the centrality of social struggle in forming and advancing them. The former allows us to break with the debilitating quietism of unmoored critique, and the latter insures we foreground the politics of human rights (and of law) in our assessments of concrete struggles and controversies. The mistake many critiques make is to present the dominant, liberal narrative of human rights, demonstrate the ways in which reality falls

\footnotetext{
100 David Harvey, The Enigma of Capital (OUP 2011) 229.

101 Terry Eagleton, Why Marx Was Right (Yale University Press 2011) 69. Similarly, Bertell Ollman argues that "'today", whenever it occurs, always emerges out of what existed yesterday, including the possibilities contained therein, and always leads (and will lead), in the very same way that it has, to what can and will take place tomorrow'. Bertell Ollman, Dance of the Dialectics: Steps in Marx's Method (University of Illinois Press 2003) 3.

$102 \mathrm{ibid} 71$. As Gramsci argued, it is 'not a question of introducing from scratch a scientific form of thought into everyone's individual life, but of renovating and making 'critical' an already existing activity'. Antonio Gramsci, Selections from the Prison Notebooks (International Publishers 1971) 330-331.
} 
This is the version of the article accepted for publication in Human Rights Quarterly published by John Hopkins University Press: https://www.press.jhu.edu/journals/human-rights-quarterly

Accepted version downloaded from SOAS Research Online: http://eprints.soas.ac.uk/24788/

short of this ideal, and from this conclude that rights are illusory, providing an ideological mask for the status quo, and, therefore, should be dropped.

The problem with this approach is that it lacks a sufficient understanding of contradiction, in the sense of a concrete contradiction, not just one of formal logic. The point is spelt out by Sean Sayers, who argues that

\begin{abstract}
All concrete things are contradictory. There are tensions and conflicts within all things and in the relations between things. This is the law of contradiction, which is the most universal expression of the philosophy of dialectics and also the least well understood. ... it is vital to understand that the dialectical concept of contradiction is not the same as the concept of contradiction in traditional formal logic.... The dialectical contradiction is a concrete contradiction: it is a contradiction which exists not just between ideas or propositions, but in things. ${ }^{103}$
\end{abstract}

He goes on to argue that 'things which are merely positive, which merely are what they are, are abstract and dead. Nothing concrete and real is merely positive. Everything is contradictory and contains negatives well as positive aspects within it. The dialectical notion of contradiction is that such conflicts between opposed aspects are necessary and essential. ${ }^{104}$

This insight of general application, that all real things are contradictory, applies equally to human rights. As Ed Sparer puts it 'the potential contribution of human rights ... coexists with their negative potential'. ${ }^{105}$ Similarly, Balakrishnan Rajagopal argues that the language of rights is 'a language of both power and resistance. It is a language of hegemony and counter-hegemony and we need to recognize the multiple uses to which it is put and the fact that it is a terrain of contestation ... for multiple deployments of both power and resistance'. ${ }^{106}$ Whereas the majority of critiques seek to iron out the imperfections, or disdain human rights for falling short of the impossible standards of liberal legalism, we do better to simply recognise that these contradictions are inevitable.

\footnotetext{
103 Sean Sayers, 'The Marxist Dialectic' (1976) 14 Radical Philosophy 9, 11 [original emphasis].

104 ibid 15 [original emphasis].

${ }^{105}$ Ed Sparer, 'Fundamental Human Rights, Legal Entitlements, and the Social Struggle: A Friendly Critique of the Critical Legal Studies Movement' (1984) 36 Stanford Law Review 509, 519.

${ }^{106}$ Balakrishnan Rajagopal, 'The International Human Rights Movement Today' (2009) 24 Maryland Journal of International Law 56, 56.
} 
This is the version of the article accepted for publication in Human Rights Quarterly published by John Hopkins University Press: https://www.press.jhu.edu/journals/human-rights-quarterly

Accepted version downloaded from SOAS Research Online: http://eprints.soas.ac.uk/24788/

Crucially, though, we must take one more step. Rejecting the sterile maximalism of unmoored critique, and acknowledging the inherently contradictory character of human rights is insufficient unless we also stress the centrality of social struggle in shaping the concrete meaning of rights in specific contexts. The point is hinted at by Rajagopal above, but made even more forcefully by Sparer, who argues that

The notion of a 'legal right' is one which can affirm and defend human autonomy and solidarity or merely give the appearance of such autonomy and solidarity while in fact excusing oppression. Various kinds of legal rights and entitlements may be used in a manner that helps to develop social movement, which in turn leads to expanded opportunities for a more humane society, or they may be used to help frustrate social movement by legitimating existing relationships. The meaning of a right or entitlement depends upon the way in which it intertwines with social movement. ${ }^{107}$

Rights, then, must be understood as struggle concepts, ${ }^{108}$ a terrain in which the interests of different groups are fought over. Starting from this understanding, rights are not imbued with some essential, trans-contextual essence, instead they are defined and re-defined in the very struggles over their meaning. ${ }^{109}$

From this perspective, then, human rights cannot be blithely dismissed as a sham, or ideological apologia for the status quo. They often are these things, but at the very same time they provide a language for critiquing and challenging the extant social order. In light of this, Sparer calls on us to build upon

the dialectics of struggle which builds upon the best of what has gone before ... We would do well to follow the radical approach of building upon our core human rights tradition, demonstrating the contradiction between that tradition and our social institutions, and developing ways to fuse human rights into new cooperative institutions of our own making. Such work require a concern for theory which feeds social movement, but successful social movement comes from the struggle for the realization of our basic rights, not from their disparagement. ${ }^{110}$

\footnotetext{
${ }^{107}$ Sparer (n 105) 560 [emphasis added].

108 Neil Stammers, Human Rights and Social Movements (Pluto Press 2009) 3.

${ }^{109}$ Hal Draper, writing about the idea of democracy, argued the meaning of it 'becomes an arena for the struggle to determine what democracy shall mean'. Hal Draper, Karl Marx's Theory of Revolution Volume I: State and Bureaucracy (Monthly Review Press 1977) 18.

110 Sparer (n 106) 539.
} 
This is the version of the article accepted for publication in Human Rights Quarterly published by John Hopkins University Press: https://www.press.jhu.edu/journals/human-rights-quarterly

Accepted version downloaded from SOAS Research Online: http://eprints.soas.ac.uk/24788/

The next two sections look at specific contexts in which the language of human rights could be mobilised (and in certain instances already is being mobilised) to defend discrete claims and interests, in a way which also calls into question the wider social system.

\section{ii. The Fight for Democracy}

It is important to remember that the modern world system was liberal and capitalist long before it was in any meaningful way democratic. ${ }^{111}$ With that said, the last forty years, in line with the expansion of neoliberal capitalism, has seen a steady erosion of democracy across the advanced capitalist world. ${ }^{112}$ Along with the decline of representation and accountability in parliamentary democracy, we have seen the steady erosion of civil and political rights, ${ }^{113}$ in part because of the so-called 'war on terror, ${ }^{114}$ but also as part of a general drift towards authoritarian neoliberalism. ${ }^{115}$ These tendencies, which were unfolding in any event, may now, following the election of Donald Trump as president of the US and broader global trends, accelerate in the coming years. ${ }^{116}$

In this context, there are two overlapping reasons why the defence of civil and political rights is important. The first is that the system of global capitalism is fundamentally incompatible with democracy, as such, the expansion of democracy, and of democratic rights and practices, is a challenge to the extant order. As Erik Olin Wright argues 'the central axis for transcending capitalism is democracy'. ${ }^{117}$ Related to this, the struggle for civil and political rights also provides space for subordinate and exploited groups to develop the political power to fundamentally challenge the order of things, and begin working to transcend the status quo. Engels was aware of this when he wrote that

The bourgeoisie cannot gain political supremacy and express this in the form of a constitution without, at the same time, arming the proletariat. On its banner it must inscribe human rights in place of the old system of social position based on birth ... for consistency's sake, it must demand universal and direct suffrage, freedom of the press, association and

\footnotetext{
111 C.B. Macpherson, The Real World of Democracy (OUP 1972) 5.

112 Peter Mair, Ruling the Void (Verso 2013).

113 See: Keith Ewing, Bonfire of the Liberties (OUP 2010); International Network of Civil Liberties Organizations (INCLO), Take Back the Streets: Repression and Criminalization of Protest Around the World (2011).

114 Radhika Desai, 'License for the New Barbarism' (2003) 29 Signs 587, 588.

115 Ian Bruff, ‘The Rise of Authoritarian Neoliberalism’ (2014) 26 Rethinking Marxism 113.

116 Stephen Hopgood, 'Fascism Rising' 09 November 2016 openDemocracy available at: https://www.opendemocracy.net/openglobalrights/stephen-hopgood/fascism-rising

${ }^{117}$ Erik Olin Wright, Envisioning Real Utopias (Verso 2009) xvi.
} 
This is the version of the article accepted for publication in Human Rights Quarterly published by John Hopkins University Press: https://www.press.jhu.edu/journals/human-rights-quarterly

Accepted version downloaded from SOAS Research Online: http://eprints.soas.ac.uk/24788/

assembly and the repeal of all emergency laws directed against particular social classes. But this is all that the proletariat need demand from the bourgeoisie. It cannot expect the bourgeoisie to stop being the bourgeoisie, but it can demand that it apply its own principles consistently. The result will be that the proletariat will lay its hands on all the weapons which it needs for its final victory. With the help of the freedom of the press and the right of association and assembly it will win universal suffrage, and by way of universal and direct suffrage, together with the means of agitation mentioned above, it will achieve everything else. ${ }^{118}$

In this way, the classic rights of liberalism, which can easily be co-opted and rendered meaningless, can also serve as important tools to allow subordinate groups to challenge the extant social order.

In the context of an increasingly authoritarian turn in global politics, the defence and protection of civil and political rights will be crucially important. If oppositional movements are to emerge and flourish, then the defence of such rights, notwithstanding their capacity for co-optation, will be essential. This point is made well by Sparer, who argued that

It is not the social legitimization which flows from the formal recognition of rights that inhibits transformative, humanizing social struggle. Many factors impede such struggle. But rights such as free speech and dissent protect the ability of groups of people - including working people - to change their society, better their group situation, and expand their human freedom. ${ }^{119}$

It is possible, and necessary, in the contemporary era to fight for civil and political rights without illusions. To recognise that such rights are, in large part, an achievement of mass movements, ${ }^{120}$ and a necessary precondition for building movements to transcend the existing order. ${ }^{121}$

\footnotetext{
118 Friedrich Engels ‘The Prussian Military Question and the German Workers’ Party' in Karl Marx, The First International and After: Political Writings Volume 3 (Verso 2010) 121, 144.

119 Sparer (n 105) 530 [original emphasis].

120 As Perry Anderson argues, the 'juridical rights of citizenship are not a mere mirage: on the contrary, the civic freedoms and suffrages of bourgeois democracy are a tangible reality, whose completion was historically in part the work of the labour movement itself, and whose loss would be a momentous defeat for the working class'. Perry Anderson, 'The Antinomies of Antonio Gramsci' (1976) I/100 New Left Review 5, 28.

121 'If we learn nothing else from twentieth century life, we should learn that the human values of autonomy and solidarity require legal expression and protection. To be sure, the very law which is necessary to protect inalienable human rights can serve to lull and confuse people and to legitimize oppression. This contradictory relationship of legal rights to human freedom and community serves only to demonstrate that legal rights, by themselves, are insufficient for their announced purposes. It is the relationship of social movement and
} 
This is the version of the article accepted for publication in Human Rights Quarterly published by John Hopkins University Press: https://www.press.jhu.edu/journals/human-rights-quarterly

Accepted version downloaded from SOAS Research Online: http://eprints.soas.ac.uk/24788/

\section{iii. Decommodification Rights}

Finally, we turn to the role that socio-economic rights can play in building movements that challenge the contemporary global order. The focus here is on one discrete, but fundamentally important aspect of the capitalist system. At the heart of capitalism is the pursuit of profit, one extension of this is an effort to commodify 'the entire life course'. ${ }^{122}$ Indeed the last forty years of so called globalisation and neoliberalism have been little more than the expansion of this logic of commodification through privatisation and various other mechanisms. If, then, commodification and the transformation of essential public goods and services into commodities is at the heart of the system, then, as Watts argues, any 'radicalism with credible claims to be representative of the Left must have as a reference point a critical stance toward capital, a formulation which sees a resistance to the commodity world as a refusal of capitalism's basic impulses'. ${ }^{123}$

It is for this reason that Patnaik places particular emphasis on struggles for socio-economic rights, as he puts it the

provision of welfare to the people in an ad hoc manner is always compatible with capitalism, since it is always reversible. But the provision of welfare as a right to the people is fundamentally incompatible with capitalism. And it is precisely why no bourgeois government can accept a rights-based approach to development; and this is also precisely why the left has to adopt a rights-based approach to development which sets it qualitatively apart from all bourgeois formations and, by unleashing a dialectics of subversion of the logic of capital, prepares the ground for a transition to socialism ... Liberal theory is unable to go beyond the confines of capitalism; it takes capitalism as its perennial premise and hence denies any rights that the bourgeois state cannot guarantee. The left position by contrast must take certain basic rights, for example rights to minimum bundles of commodities, services, and material security ... as its premise and hence not confine itself to the boundaries of bourgeois society. This is exactly what a rights-based approach seeks to do; and notwithstanding all appearances to the contrary such an approach can never be accepted by any bourgeois formation. ${ }^{124}$

struggle to the use of legal rights which is determinative. In short, legal recognition of the inalienable human rights is a necessary, even though manifestly insufficient, protection against oppression'. Sparer (n 106) 514.

122 Robin Blackburn, 'Crisis 2.0' (2011) 72 New Left Review 33, 35.

${ }^{123}$ Michael Watts, 'Now and Then' (2009) 41 Antipode 10, 23.

124 Patnaik (n 63) 35-36. 
This is the version of the article accepted for publication in Human Rights Quarterly published by John Hopkins University Press: https://www.press.jhu.edu/journals/human-rights-quarterly

Accepted version downloaded from SOAS Research Online: http://eprints.soas.ac.uk/24788/

If commodification and market dependence are 'the essence of the system', ${ }^{125}$ then claims that certain things (goods and services) are so fundamental to human flourishing that they should be exempted from market rationality, can introduces a logic of decommodification, ${ }^{126}$ which poses a fundamental challenge to the existing order.

Such a conception of socio-economic rights is one which goes beyond established doctrinal accounts, ${ }^{127}$ and instead draws on the articulations of social movements engaged in struggles for their vital interests. In this way, struggle remains centre stage and works to advance claims around particular interests, but also, as Patnaik argues, to provide a political education of the communities and groups involved. As he puts it

Political praxis on the part of the people ... is the weapon for transcending ... capitalism. In this struggle, every welfare gain they make strengthens them. And since "rights" are guarantors of welfare gains, every winning of "rights" likewise strengthens them. The acquisition of "rights" on the part of the people, including rights to minimum bundles of goods, services and security, amounts therefore to winning crucial battles in the class war for the transcendence of capitalism. The left's putting on its agenda a struggle for people's "rights", adopting a "rights based approach" to development as opposed to the "means-based approach" of the bourgeois ... constitutes therefore not a retreat into humanism but an integral part of the dialectics of subversion of the logic of capital. ${ }^{128}$

In the contemporary era of austerity and commodification, communities struggling for water, housing, health care and food find that their immediate struggle also requires thinking about broader, structural issues. The assertion of a human right, in these contexts, becomes, of necessity, a rejection of the logic of the market, of the basic impulse of the capitalist system.

\footnotetext{
125 Wood (n 98) 29.

126 Where 'a service is rendered as a matter of right, and when a person can maintain a livelihood without reliance on the market'. Gosta Esping-Andersen, The Three Worlds of Welfare Capitalism (Polity Press 1990) 21 22.

${ }^{127} \mathrm{UN}$ agencies, and other official bodies, have long sought to maintain an agnostic or a-political stance, insisting that human rights can be realised under myriad economic and social arrangements. See, for example, the former UN Special Rapporteur on the Right to Health, Paul Hunt, who argued that, subject to certain caveats, 'International human rights law takes a position neither for nor against any particular trade rule or policy'. Paul Hunt, 'Report of the Special Rapporteur on the right of everyone to the enjoyment of the highest attainable standard of physical and mental health Mission to the World Trade Organisation' (UN Doc E/CN.4/2004/49/Add.1) Para 11.

128 Patnaik (n 63) 37.
} 
This is the version of the article accepted for publication in Human Rights Quarterly published by John Hopkins University Press: https://www.press.jhu.edu/journals/human-rights-quarterly

Accepted version downloaded from SOAS Research Online: http://eprints.soas.ac.uk/24788/

\section{CONCLUSION}

Critiques of human rights highlight crucial shortcomings in the dominant, liberal discourse. However, shifting the frame of reference and situating discussions of human rights within a Marxist tradition that emphasises contradiction, social struggle, and the need to transcend the system which structurally undermines human flourishing, opens a way of understanding human rights that can support movements for radical social change. Of course, the assertion of human rights will not bring about fundamental transformation in and of itself, ${ }^{129}$ but they can play an important role in broader struggles to do that. In the early 1990s Anthony Chase argued that in the coming century a 'crucial confrontation will occur between essentially authoritarian public and private power, on the one hand, and rights-based anti-systemic movements, on the other'. ${ }^{130}$ His observations may prove prescient, and if that is the case, then it is clear that movements for fundamental change will need to draw on radical, emancipatory theories, such as Marxism, in order to avoid the pitfalls of liberal legalism.

\footnotetext{
${ }^{129}$ As Stathis Kouvelakis puts it 'one can restate 'egaliberte' and 'citizenship' as often as one likes, but one will never thereby obtain the 'transformation of the relations of production', 'seizure of power', 'abolition of wage labor, of the market, and of classes' or the 'withering away of the state'. Kouvelakis (n 18) 718.

130 Anthony Chase, 'The Rule of Law and the Capitalist State: Bills of Rights in Jeopardy' (1991) 65 St. John's Law Review 85, 117.
} 